\section{(2) OPEN ACCESS}

\title{
Takayasu arteritis in a rural hospital in Indonesia
}

\author{
Michael Lusida 다, ${ }^{1}$ Mohammad Zakky Kurniawan, ${ }^{2}$ Johanes Nugroho ${ }^{3}$
}

${ }^{1}$ General Practice and Primary Care, RSUD Dr R Soedarsono, Pasuruan, Indonesia ${ }^{2}$ Cardiology, RSUD Dr R Soedarsono, Pasuruan, Indonesia ${ }^{3}$ Cardiology, RSUD Dr Soetomo, Surabaya, Surabaya, Indonesia

\section{Correspondence to}

Michael Lusida;

michaellusida@gmail.com

Accepted 28 December 2019

Check for updates

(c) BMJ Publishing Group Limited 2020. Re-use permitted under CC BY-NC. No commercial re-use. See rights and permissions. Published by BMJ.

To cite: Lusida $\mathrm{M}$,

Kurniawan $\mathrm{MZ}$,

Nugroho J. BMJ Case

Rep 2020;13:e230884.

doi:10.1136/bcr-2019-

230884

\section{SUMMARY}

Takayasu arteritis (TA) is a rare chronic granulomatous inflammation of the aorta or its branches and is prevalent all around the world. It causes stenosis of large arteries and ischaemic damage to target organs. There is usually a delay in recognising TA because of the rarity and unfamiliarity with the disease, unspecific early symptoms and lack of diagnostic equipment for early diagnosis. In this report, we present a case of an 18-yearold woman from Pasuruan, East Java, Indonesia, with recurrent fever, headache, claudication of extremities and postprandial abdominal pain. She was diagnosed clinically with suspicion of TA and was sent to a tertiary hospital to confirm the diagnosis. Arteriography revealed that the patient had narrowing of the thoracic and abdominal aorta until the level of the aortic bifurcation. The patient was started on high-dose corticosteroid, cyclosporine A and diltiazem. The patient then showed improvement in her symptoms.

\section{BACKGROUND}

Takayasu arteritis (TA) is a rare systemic disease more frequently found in Asian countries but is prevalent all over the world. In Japan, 100-200 new cases of TA are found every year. In the United States, the incidence for TA is only approximately 2.6 cases per million people every year. ${ }^{1-4}$ To the author's knowledge, there has not been any case report or studies published to date regarding the epidemiology of TA in Indonesia.

TA is a disease that can cause debilitating complications if left untreated. Therefore, early recognition and prompt treatment are key to managing patients with TA. ${ }^{2-4}$ Early diagnosis, however, is challenging because of the disease's unspecific early signs and symptoms, especially in locations where medical professionals are not familiar with the disease. Diagnosis of TA becomes more challenging in rural areas where diagnostic arteriography is not available. Herein, we present a case of an 18-year-old woman from Pasuruan, East Java, Indonesia, who was diagnosed with TA.

\section{CASE PRESENTATION}

An 18-year-old Japanese woman presented to the cardiology office with a 2-year history of chronic recurrent fever and malaise. These episodes of fever were accompanied by headaches and discomfort in her arms and legs, which became more severe with physical activity. She also frequently reported abdominal discomfort after eating. The patient had previously seen a primary care physician and was diagnosed with typhoid fever and was given antipyretics and antibiotics; however, the symptoms persisted. The patient had a history of uncontrolled hypertension, which was known since she was 7 years old.

During the physical examination, there was a remarkable blood pressure discrepancy between the right and left arms. Blood pressure was 120/90 mm $\mathrm{Hg}$ in the left arm and was $142 / 76 \mathrm{~mm} \mathrm{Hg}$ in the right arm. The left and right radial pulses were hard to palpate, and the lower extremities were cold and clammy. Her heart rate was 110 beats/min, and her body temperature was $37^{\circ} \mathrm{C}$. There was conjunctival pallor and a II/III systolic murmur at the apex. There was also bruit over the left and right carotid and subclavian artery.

\section{INVESTIGATIONS}

Chest radiography and ECG showed no abnormality. Transthoracic echocardiography showed mitral regurgitation and pulmonic valve prolapse. The abdominal ultrasound showed signs of bilateral renal artery stenosis.

Significant laboratory findings included elevated erythrocyte sedimentation rate (ESR) $(120 \mathrm{~mm} / 2$ hours $)$ and hypochromic microcytic anaemia. The renal and liver function tests were normal.

A tentative diagnosis of TA was made, and the patient was then referred to a tertiary hospital due to limitations of diagnostic equipment in our hospital.

\section{OUTCOME AND FOLLOW-UP}

In the follow-up, the patient was asymptomatic. Her blood pressure was $120 / 90 \mathrm{~mm} \mathrm{Hg}$ in the left arm and 140/90 $\mathrm{mm} \mathrm{Hg}$ in the right arm. The ESR was $30 \mathrm{~mm} / 2$ hours. Transthoracic echocardiography showed mild mitral regurgitation and trivial aortic regurgitation. Aortic catheterisation and digital subtraction angiography (figure 1) had been performed in the tertiary hospital and showed a narrowing of the thoracic and abdominal aorta until the level of aortic bifurcation, with the highest degree of stenosis up to $60 \%$ proximal to the branching out of renal arteries (video 1). Subsequent duplex ultrasound showed some stenosis of the right common carotid artery with increased intimamedia thickness (figure 2). Ultrasound of the subclavian and axillary arteries was normal.

The patient received treatment from the tertiary hospital, which comprised oral methylprednisolone $(40 \mathrm{mg} /$ day $)$, oral cyclosporine $(50 \mathrm{mg} /$ day $)$ and oral diltiazem $(100 \mathrm{mg} /$ day). Methylprednisolone was then gradually tapered to $8 \mathrm{mg} /$ day. With the 


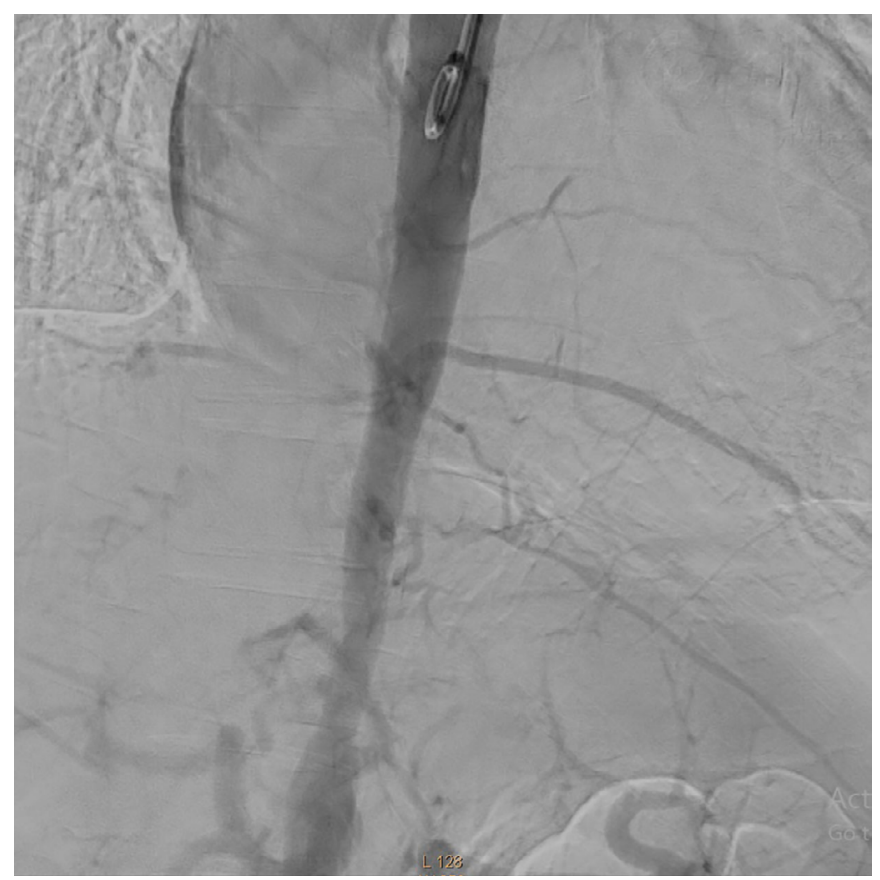

Figure 1 The digital subtraction angiography of the thoracic and the abdominal aorta.

treatment, the patient remains asymptomatic until the writing of this case report.

\section{DISCUSSION}

In our case, an 18-year-old woman presented with recurrent fever, claudication of limbs, postprandial abdominal pain, a difference of $>10 \mathrm{~mm} \mathrm{Hg}$ in systolic blood pressure between arms and bruits that could be heard along both the carotid and subclavian arteries. These were caused by the narrowing of the subclavian artery and the abdominal aorta and reflected

Video 1 The digital subtraction angiography showing a narrowed thoracic and abdominal aorta.

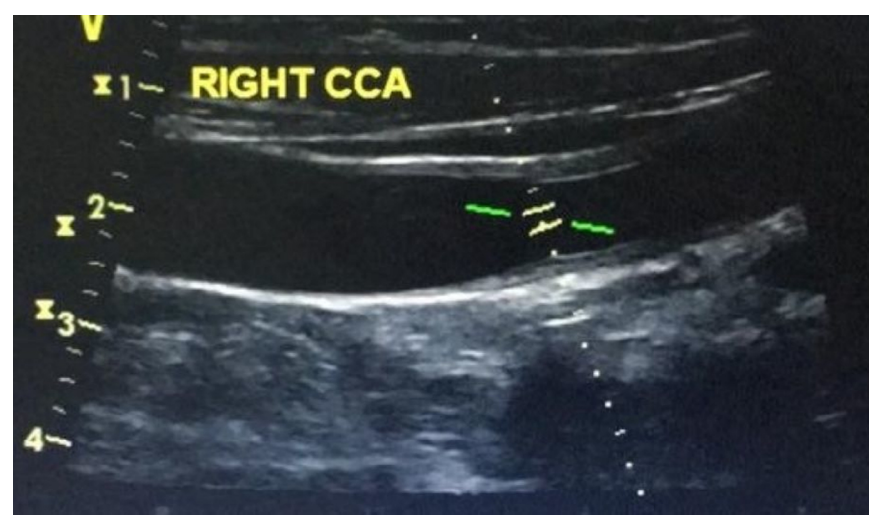

Figure 2 The duplex ultrasound of the right common carotid artery showing narrowing and increased intimamedia thickening $(1.79 \mathrm{~mm})$.

end-organ ischaemia. Even without arteriography, the clinical findings in our patient met four out of six TA criteria defined by the American College of Rheumatology. ${ }^{1356}$ The presence of three or more out of the six criteria is known to have a sensitivity of $90.5 \%$ and specificity of $97.8 \% .{ }^{56}$ Our patient also met all the clinical criteria European League Against Rheumatism/ Pediatric Rheumatology International Trials Organization/Pediatric Rheumatology European Society criteria for childhood TA, which has a sensitivity and specificity of $100 \%$ and $99.9 \% .{ }^{67} \mathrm{TA}$ was then suspected, and the narrowing of the blood vessel was then confirmed by digital subtraction arteriography and duplex ultrasound done in the tertiary hospital.

Differential diagnoses, in this case, include other primary vasculitides, which can manifest as constitutional symptoms, joint pain and muscle weakness. These vasculitides include giant cell arteritis, polyarteritis nodosa, Henoch-Schonlein purpura, granulomatosis with polyangiitis (GPA) and eosinophilic granulomatosis with polyangiitis (EGPA). Giant cell arteritis usually manifests in older women and can be ruled out due to the early age of onset of the disease. ${ }^{8}$ Polyarteritis nodosa usually manifests as renal insufficiency, neuropathy, with alternating microaneurysm and constriction of the affected blood vessels in arteriography. ${ }^{9}$ The absence of renal insufficiency, neuropathy and imaging findings rules out this disease. Henoch-Schonlein purpura is a small vessel vasculitis that usually affects children. It manifests as palpable purpura on the lower half of the body and glomerulonephritis, the absence of which rules out the disease. ${ }^{10}$ Microscopic polyangiitis and GPA are small to middle size vessel vasculitides that usually manifest as haematuria and haemoptysis. $^{11}$ EGPA is similar to GPA with the addition of $>10 \%$ eosinophilia and a history of asthma. ${ }^{12}$ These three vasculitides are known for their association with positive serum antineutrophilic antibodies (ANCA). ${ }^{1112}$ While a test for serum ANCA was not available in our hospital, our patient did not have the usual findings attributed to these diseases, such as skin lesion, haemoptysis and renal insufficiency. None of the vasculitides mentioned above has a discrepancy of blood pressures between the right and the left arm as a clinical finding. ${ }^{8-12}$

In our patient, the disease affected both the superior branches of the aorta, as supported by the physical examination, and the abdominal aorta, with the highest degree of stenosis in the abdominal aorta. This clinical presentation matches type V TA, as classified in the Takayasu Conference in $1994 .^{13}$

The treatment for TA consists of immunosuppressant therapy. High-dose corticosteroid is the mainstay of the therapy, although tapering of the dose can sometimes cause relapses of the disease. 
It is recommended to add a second immunosuppressive agent such as methotrexate, cyclosporine A, tacrolimus, azathioprine, cyclophosphamide and mycophenolate mofetil. ${ }^{3}{ }^{13}{ }^{14}$ In this patient, diltiazem is also added to manage hypertension.

Multiple studies have shown the benefit of stenting or surgery to correct severe stenosis. ${ }^{14}{ }^{15}$ Indications for surgery include uncontrolled hypertension as a consequence of renal artery stenosis, severe symptomatic coronary artery or cerebrovascular disease, severe aortic regurgitation or coarctation, stenotic or occlusive lesions resulting in critical limb ischaemia and aneurysms at risk of rupture. ${ }^{15}$

As noted above, TA is a disease of chronic granulomatous inflammation of the aorta or its branches. This inflammation will eventually cause fibrinoid necrosis, and fibrosis, narrowing and aneurysm of the vessel wall. ${ }^{13}$ TA manifestation can be divided into two phases: an initial phase of unspecific findings, for example, fever, malaise and headache, and a late stenotic phase characterised by findings such as hypertension, claudication, pulselessness, bruit and angina. ${ }^{13} 141617$ If left untreated, TA will eventually cause irreversible target organ damage and severe morbidity.

The diagnosis of TA has always been a challenge. Multiple case reports and studies have shown that the diagnosis of TA is usually delayed 10 months to 12 years, with $91 \%$ of patients reporting having seen at least one physician before diagnosis. ${ }^{151819}$ By the time of diagnosis, the patient usually has already suffered significant morbidity. In our case, the diagnosis was delayed by 2 years. However, the disease may have existed for a longer period since it cannot be ascertained whether the patient's childhood hypertension had been a result of TA progression.

This delay of diagnosis can be attributed to a few factors. First, both the early and late manifestation of TA is not specific. ${ }^{19}$ Laboratory findings include acute-phase reactant markers or ESR, which are not specific for TA. ${ }^{13-15} 18$ The advent of noninvasive imaging modalities, for example, MR arteriography (MRA), CT angiography (CTA) and positron emission tomography with ${ }^{18}$ F-FDG (FDG-PET), have helped diagnose TA even in the prestenotic phase. ${ }^{15}{ }^{18-20}$ FDG-PET is a functional imaging tool that can detect inflammation in the vessel wall and has a demonstrated pooled sensitivity of $87 \%$ and specificity of $73 \%$ for the assessment of TA. MRA and CTA are usually used in conjunction with FDG-PET to detect structural changes and complications. ${ }^{20}$ These tools, however, are not readily available in rural hospitals. They are also very expensive and are not covered by the Indonesian government health insurance programme, which is the primary method of payment used in rural areas. Therefore, the most crucial factor of early diagnosis is the physician's awareness of the clinical findings. ${ }^{15} 1819$

Although not specific, duplex ultrasound can provide evidence of stenosis in the arteries affected by TA. ${ }^{21}$ In our patient, duplex ultrasound performed in the tertiary hospital showed stenosis in the right common carotid artery with increased intimamedial thickness (figure 2). The classic finding of TA in ultrasound is stenosis with a homogeneous hypoechoic circumferential thickening of the intimamedia complex, also known as the macaroni sign. This finding is absent in our patient, most likely due to the ultrasound being performed after months of treatment.

Another cause of delay in this patient lies in the unfamiliarity of physicians with the disease. ${ }^{18} 19$ Indonesia is a tropical country and is endemic to many infectious diseases, such as enteric fever. Therefore, it is more likely that infectious disease is suspected first in a patient with fever. ${ }^{22}$ Another cause of unfamiliarity with TA is the rarity of the disease and the lack of case reports or studies about TA in Indonesia.
Box 1 Red flag findings for Takayasu arteritis in patients under the age of 40 years

Carotidynia
Angina
Limb claudication
Absent/weak peripheral pulses
Hypertension
Discrepant blood pressure in the upper limbs $(>10 \mathrm{~mm} \mathrm{Hg})$
Arterial bruits
Aortic regurgitation
Unexplained acute-phase response (elevated erythrocyte
sedimentation rate or C-reactive protein)

Since the most important factor for early diagnosis of TA is the physician's awareness of the findings, Nazareth and Mason proposed 'red flag' signs and symptoms that should direct physicians' suspicion to TA (box 1). ${ }^{18}$ In this patient, seven out of nine findings were found in our patient.

\section{Learning points}

Early diagnosis is paramount in managing Takayasu arteritis (TA) to prevent morbidity

- In tropical areas, physicians should always consider TA in a patient with recurrent fever and increased acute-phase reactants, while eliminating infection as a possible cause.

- Difficulties of diagnosing TA in rural setting includes the rarity and unfamiliarity with the disease, unspecific early symptoms and lack of diagnostic equipment for early diagnosis.

- More studies should be done regarding TA in Indonesia.

Contributors $\mathrm{ML}$ is responsible for the acquisition of the clinical information of the patient and drafting the manuscript. MZK is responsible for the conception, revision and the approval of the manuscript. JN contributed to the revision and the approval of the manuscript and provided the image and video used in the manuscript.

Funding The authors have not declared a specific grant for this research from any funding agency in the public, commercial or not-for-profit sectors.

\section{Competing interests None declared.}

\section{Patient consent for publication Obtained.}

Provenance and peer review Not commissioned; externally peer reviewed.

Open access This is an open access article distributed in accordance with the Creative Commons Attribution Non Commercial (CC BY-NC 4.0) license, which permits others to distribute, remix, adapt, build upon this work non-commercially, and license their derivative works on different terms, provided the original work is properly cited and the use is non-commercial. See: http://creativecommons.org/ licenses/by-nc/4.0/.

\section{ORCID iD}

Michael Lusida http://orcid.org/0000-0002-0172-3329

\section{REFERENCES}

1 Hall S, Barr W, Lie JT, et al. Takayasu arteritis. A study of 32 North American patients. Medicine 1985;64:89-99.

2 Jain S, Kumari S, Ganguly NK, et al. Current status of Takayasu arteritis in India. Int J Cardiol 1996;54(Suppl):S111-6.

3 Johnston SL, Lock RJ, Gompels MM. Takayasu arteritis: a review. J Clin Pathol 2002;55:481-6.

4 Numano F, Kobayashi Y. Takayasu arteritis--beyond pulselessness. Intern Med 1999:38:226-32

5 Arend WP, Michel BA, Bloch DA, et al. The American College of rheumatology 1990 criteria for the classification of Takayasu arteritis. Arthritis Rheum 1990:33:1129-34.

6 de Souza AWS, de Carvalho JF. Diagnostic and classification criteria of Takayasu arteritis. J Autoimmun 2014;48-49:79-83. 
7 Ozen S, Pistorio A, lusan SM, et al. EULAR/PRINTO/PRES criteria for Henoch-Schönlein purpura, childhood polyarteritis nodosa, childhood Wegener granulomatosis and childhood Takayasu arteritis: Ankara 2008. Part II: final classification criteria. Ann Rheum Dis 2010;69:798-806.

8 Alberts M. Temporal arteritis: improving patient evaluation with a new protocol. Perm 2013:17:56-62.

9 He Q, Shu J, Chen F, et al. Analysis of the clinical characteristics and followup study of children with cutaneous polyarteritis nodosa. Curr Neurovasc Res 2019;16:208-14.

10 Hetland LE, Susrud KS, Lindahl KH, et al. Henoch-Schönlein purpura: a literature review. Acta Derm Venereol 2017;97:1160-6.

11 Lutalo PMK, D'Cruz DP. Diagnosis and classification of granulomatosis with polyangiitis (AKA Wegener's granulomatosis). J Autoimmun 2014;48-49:94-8.

12 Groh M, Pagnoux C, Baldini C, et al. Eosinophilic granulomatosis with polyangiitis (Churg-Strauss) (EGPA) consensus Task force recommendations for evaluation and management. Eur J Intern Med 2015;26:545-53.

13 Mann DL, Zipes D, Libby P, et al, eds. Braunwald's heart disease: a textbook of cardiovascular medicine, single volume. 10th edn. Philadelphia, PA: Elsevier/Saunders, 2015.

14 Keser G, Direskeneli H, Aksu K. Management of Takayasu arteritis: a systematic review. Rheumatology 2014;53:793-801.
15 Perera AH, Mason JC, Wolfe JH. Takayasu arteritis: criteria for surgical intervention should not be ignored. Int J Vasc Med 2013;2013:8.

16 Espinoza JL, Ai S, Matsumura I. New insights on the pathogenesis of Takayasu arteritis: revisiting the microbial theory. Pathogens 2018;7:E73.

17 Lee S-H, Lee MJ, Kang B, et al. A case report of patient with Takayasu's arteritis complicated by reversible cerebral vasoconstriction syndrome. J Rheum Dis 2013;20:194.

18 Nazareth R, Mason JC. Takayasu arteritis: severe consequences of delayed diagnosis. QJM 2011;104:797-800.

19 Watson L, Brogan P, Peart I, et al. Diagnosis and assessment of disease activity in Takayasu arteritis: a childhood case illustrating the challenge. Case Rep Rheumatol 2014;2014:6.

20 Slart RHJA, Writing group, Reviewer group. FDG-PET/CT(A) imaging in large vessel vasculitis and polymyalgia rheumatica: joint procedural recommendation of the EANM, SNMMI, and the PET Interest Group (PIG), and endorsed by the ASNC. Eur J Nucl Med Mol Imaging 2018;45:1250-69.

21 Siepmann T, Bodechtel U. Teaching Neurolmages: macaroni sign. Neurology 2014;83:e11.

22 Purba I, Wandra T, Nugrahini N, et al. Program Pengendalian Demam Tifoid di Indonesia: Tantangan DAN Peluang. Media Penelitian dan Pengembangan Kesehatan 2016;26.

Copyright 2020 BMJ Publishing Group. All rights reserved. For permission to reuse any of this content visit https://www.bmi.com/company/products-services/rights-and-licensing/permissions/ BMJ Case Report Fellows may re-use this article for personal use and teaching without any further permission.

Become a Fellow of BMJ Case Reports today and you can:

- Submit as many cases as you like

- Enjoy fast sympathetic peer review and rapid publication of accepted articles

- Access all the published articles

- Re-use any of the published material for personal use and teaching without further permission

Customer Service

If you have any further queries about your subscription, please contact our customer services team on +44 (0) 2071111105 or via email at support@bmj.com. Visit casereports.bmj.com for more articles like this and to become a Fellow 